Archives of Agriculture and Environmental Science

\title{
Impact of nutrient management on the yield performance of some aromatic fine rice (Oryza sativa L.) varieties in Boro season
}

\section{Antora Adhikari, Md Abdur Rahman Sarkar, Swapan Kumar Paul* (iD and Kallyan Kanty Saha}

Department of Agronomy, Bangladesh Agricultural University, Mymensingh 2202, BANGLADESH

"Corresponding author's E-mail: skpaul@bau.edu.bd

\section{ARTICLE HISTORY}

Received: 02 July 2018

Revised received: 07 August 2018

Accepted: 17 August 2018

\section{Keywords}

Aromatic fine rice

Boro season

Integrated nutrient management

Yield performance

\begin{abstract}
An experiment was conducted at the Agronomy Field Laboratory, Bangladesh Agricultural University, Mymensingh, during November 2016 to April 2017 to study the impact of nutrient management on the performance of aromatic fine rice in Boro season. The experiment comprised three varieties viz., BRRI dhan50, Basmati and BRRI dhan63; and seven nutrient managements viz., poultry manure @ $5 \mathrm{t} \mathrm{ha}^{-1}$, recommended dose of chemical fertilizers (i.e.

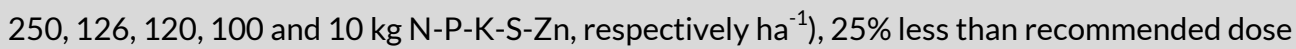
of chemical fertilizer + poultry manure @ $2.5 \mathrm{t} \mathrm{ha}^{-1}, 50 \%$ less than recommended dose of chemical fertilizer + poultry manure @ $5 \mathrm{t} \mathrm{ha}^{-1}$, vermicompost @ $10 \mathrm{t} \mathrm{ha}^{-1}, 25 \%$ less than recommended dose of chemical fertilizer + vermicompost $5 \mathrm{t} \mathrm{ha}^{-1}, 50 \%$ less than recommended dose of chemical fertilizer + vermicompost @ $10 \mathrm{t} \mathrm{ha}^{-1}$. The experiment was laid out in a randomized complete block design with three replications. The results revealed that variety, nutrient management and their interaction exerted significant influence on yield components and yield of aromatic fine rice in Boro season. The highest grain yield $\left(4.09 \mathrm{t} \mathrm{ha}^{-1}\right)$, straw yield $\left(6.20 \mathrm{t} \mathrm{ha}^{-1}\right)$ and harvest index (39.37\%) were obtained in BRRI dhan63 while the lowest grain yield (3.44 t $\mathrm{ha}^{-1}$ ) and harvest index (36.54\%) were found in Basmati. In case of nutrient management, the highest grain yield ( $4.31 \mathrm{t} \mathrm{ha}^{-1}$ ) was recorded in recommended dose of chemical fertilizers (i.e.

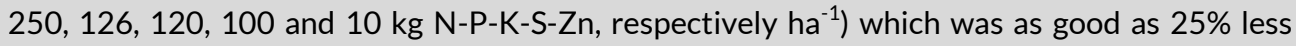
than recommended dose of chemical fertilizer + vermicompost @ $5 \mathrm{t} \mathrm{ha}{ }^{-1}$ and $25 \%$ less than recommended dose of chemical fertilizer + poultry manure @ $2.5 \mathrm{t} \mathrm{ha}^{-1}$ while the lowest one $\left(2.74 \mathrm{t} \mathrm{ha}^{-1}\right.$ ) was found in vermicompost @ $10 \mathrm{t} \mathrm{ha}^{-1}$. In case of interaction, the highest grain yield $\left(5.30 \mathrm{tha}^{-1}\right)$ was obtained in BRRI dhan 63 along with $50 \%$ less than recommended dose of chemical fertilizer + vermicompost @ $10 \mathrm{t} \mathrm{ha}^{-1}$ while the highest straw yield $\left(7.20 \mathrm{t} \mathrm{ha}^{-1}\right)$ was produced in BRRI dhan63 fertilized with recommended dose of chemical fertilizers (i.e. 250,

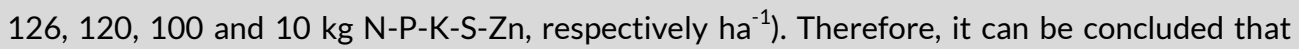
BRRI dhan63 can be grown with $50 \%$ less than recommended dose of chemical fertilizer + vermicompost @10 tha ${ }^{-1}$ in Boro season to obtain the highest grain yield.
\end{abstract}

(C)2018 Agriculture and Environmental Science Academy

Citation of this article: Adhikari, A., Sarkar, M.A.R., Paul, S.K. and Saha, K.K. (2018). Impact of nutrient management on the yield performance of some aromatic fine rice (Oryza sativa L.) varieties in Boro season. Archives of Agriculture and Environmental Science, 3(3): 245-251, https://dx.doi.org/10.26832/24566632.2018.030306

\section{INTRODUCTION}

Bangladesh is one of the most important rice growing countries of the world. In respect of area and production, Bangladesh ranks fourth among the rice producing countries of the world following China, India and Indonesia (FAO, 2009). About
$77.07 \%$ of cropped area of Bangladesh is used for rice production, with annual production of 34.71 million ton from 11.42 million ha of land (BBS, 2016). Boro rice covers about $41.94 \%$ of total rice area in the country (BBS, 2016). Aromatic rice contributes a small portion (10\%) but an important subgroup of rice production. Total aromatic rice production is about 0.297 
million tons in 2013 from 0.158 million ha of land in Bangladesh. Sarkar et al. (2014) reported that Bangladesh has a bright prospect for export of fine rice thereby earning foreign exchange. The yield of fine rice is lower than that of coarse and medium rice varieties. In recent years, aromatic rice has been introduced to the global market because of its taste, deliciousness and high price to boost up the economic condition of the rice grower in the developing countries like Bangladesh. Because of its natural chemical compounds which give it a distinctive scent or aroma when cooked, aromatic rice commands higher price than nonaromatic rice. The demand of aromatic rice for internal consumption and also for export is increasing day by day. For this reason, farmers are willing to grow aromatic fine rice to obtain higher economic return. So, it is high time to increase the production of aromatic fine rice through increasing the yield per unit area by following proper management system of crop cultures especially through developed variety and nutrient management. In Bangladesh, more than 37 aromatic rice cultivars are grown. Such common cultivars are Kataribhog, Chinigura, Chinisagar, Badshabhog, Rasulbhog, Radhunipagol, Kalizira, Tulshimala, Dulabhog, Basmati, BRRI dhan34, BRRI dhan37, BRRI dhan38, Binadhan-9 and Binadhan-13. Most of the scented rice varieties in Bangladesh are of traditional type, photoperiod sensitive, and cultivated during the Aman season. One variety is recommended for Boro season namely, BRRI dhan50 (Banglamoti) developed by the Bangladesh Rice Research Institute (BRRI) has gained huge popularity among farmers for its fragrance and relatively high productivity. Like other crops, the yield level of rice, the staple food grain of the country, is very low (2.876 t ha ${ }^{-1}$ ) (BBS, 2016) compared to other rice growing countries like South Korea and Japan where the average yield is 6.00 and $5.22 \mathrm{t} \mathrm{ha}^{-1}$, respectively (FAO, 2004). The reason for low yields are mainly associated with lack of improved varieties and judicious fertilizer management especially of organic manure like cowdung, vermicompost, poultry manure and/or their integration with inorganic fertilizers. In Bangladesh, nutrient stresses of soils are increasing day by day. The productivity of aromatic fine rice in Bangladesh is very low due mainly to proper nutrient management. The efficient nutrient management increases crop yield and at the same time reduces fertilization cost. Therefore, extensive research works are necessary to find out appropriate variety and optimum rate of poultry manure, vermicompost in combination with inorganic fertilizers to obtain satisfactory yield and quality of fine rice.

\section{MATERIALS AND METHODS}

\section{Description of study site}

The experiment was conducted at the Agronomy Field Laboratory, Bangladesh Agricultural University, Mymensingh, during November 2016 to April 2017. This experimental site is located at $24^{\circ} 75^{\prime} \mathrm{N}$ latitude and $90^{\circ} 50^{\prime} \mathrm{E}$ longitude having an altitude of $18 \mathrm{~m}$. The experimental site belongs to the Sonatala series of Old Brahmaputra Floodplain Agroecological Zone (AEZ-9) having non -calcareous dark grey floodplain soils (UNDP and FAO, 1988).
Experimental design and treatment details

The experiment consisted of three varieties viz. BRRI dhan50, Basmati and BRRI dhan63, and seven nutrient managements viz., poultry manure $5 \mathrm{t} \mathrm{ha}^{-1}$, recommended dose of chemical fertilizers (i.e. 250, 126, 120, 100 and $10 \mathrm{~kg} \mathrm{N-P-K-S-Zn,} \mathrm{respec-}$ tively $\mathrm{ha}^{-1}$ ), $25 \%$ less than recommended dose of chemical fertilizer + poultry manure @ $2.5 \mathrm{t} \mathrm{ha}^{-1}, 50 \%$ less than recommended dose of chemical fertilizer + poultry manure @ $5 \mathrm{t} \mathrm{ha}^{-1}$, vermicompost @ $10 \mathrm{t} \mathrm{ha}^{-1}$, 25\% less than recommended dose of chemical fertilizer + vermicompost @ $5 \mathrm{t} \mathrm{ha}^{-1}$, 50\% less than recommended dose of chemical fertilizer + vermicompost @ 10 $\mathrm{t} \mathrm{ha}^{-1}$. The experiment was laid out in a randomized complete block design with three replications. At the time of final land preparation, respective unit plots were fertilized with different levels of vermicompost, poultry manure according to treatments. The manures were thoroughly mixed with the soil. The amount of nitrogen, phosphorus, potassium, sulphur and zinc required for each unit plot was calculated on ha ${ }^{-1}$ basis and applied in the form of urea, triple super phosphate, muriate of potash, gypsum and zinc sulphate, respectively. Triple super phosphate, muriate of potash, gypsum and zinc sulphate was applied at final land preparation as per treatment. Urea was applied in three equal splits at 15, 30 and 45 days after transplanting (DAT).

\section{Transplantation of seedlings and collection of data}

Thirty-five days old seedlings were uprooted carefully without causing any mechanical injury to the root. Healthy seedlings were transplanted in the well puddled experimental plots on 21 December 2016. Intercultural operations were done for ensuring and maintaining normal growth of the crop when necessary. Prior to harvest five hills (excluding border hills) were selected randomly from each unit plot and uprooted to record data on crop characters and yield components. After sampling, the whole plot was harvested at maturity when $90 \%$ of the grains became golden yellow in color. BRRI dhan63 was harvested on 23 April, 2017 and BRRI dhan50 and Basmati were harvested on 30 April 2017. The harvested crops of each plot was separately bundled, properly tagged and then brought to threshing floor. Threshing was done manually. The grains were cleaned and sun dried to $14 \%$ moisture content. Straws were also dried properly. Finally grain and straw yields plot $^{-1}$ were recorded and converted to $\mathrm{t} \mathrm{ha}^{-1}$. Harvest index (\%) was calculated with the following formula:

$$
\text { Harvest index }(\%)=\frac{\text { Grain yield }}{\text { Biological yield }} \times 100
$$

\section{Statistical analysis of data}

Data were analyzed statistically using "Analysis of Variance" technique and differences among treatments means were adjudged by Duncan's Multiple Range Test (DMRT) (Gomez and Gomez, 1984). 


\section{RESULTS AND DISCUSSION}

\section{Varietal performance}

Yield components and yield of aromatic fine rice were significantly influenced by variety (Table 1 ). BRRI dhan 50 produced the highest plant height $(69.43 \mathrm{~cm})$, which was statistically identical to Basmati $(67.48 \mathrm{~cm})$ and the lowest one $(66.30 \mathrm{~cm})$ was found in BRRI dhan63. The variation in plant height among the varieties was probably due to heredity or varietal characters. Similar results were reported elsewhere (Paul et al., 2016; Ray et al., 2015 and Kirttania et al., 2013). The highest number of total tillers hill $^{-1}$ was produced by Basmati (10.47), which was statistically identical to BRRI dhan50 (10.33) and the lowest one (9.47) was found in BRRI dhan63. Shaha et al. (2014) reported that number of tillers hill ${ }^{-1}$ was influenced by variety. BRRI dhan 50 and Basmati produced the highest and same number of effective tillers (9.00) and statistically identical panicle length $(21.29 \mathrm{~cm}$ and $21.10 \mathrm{~cm}$, respectively) while the lowest of these parameters were found in BRRI dhan63. Due to varietal characteristics production of effective tillers hill ${ }^{-1}$ varied significantly (Sarkar et al., 2014). Shaha et al. (2014) reported that panicle length was influenced with variety. Basmati and BRRI dhan63 produced the highest and same number of non-effective tillers (1.47) and the lowest one (1.33) was found in BRRI dhan50. The highest number of grains panicle ${ }^{-1}(97.67)$ and number of total spikelets panicle ${ }^{-1}(107.8)$ was found in BRRI dhan 50 while BRRI dhan63 produced the highest number of sterile spikelets panicle ${ }^{-1}$ (15.29), 1000-grain weight (20.96 g), grain yield (4.09 $\left.\mathrm{t} \mathrm{ha}^{-1}\right)$, straw yield $\left(6.20 \mathrm{t} \mathrm{ha}^{-1}\right)$, biological yield $\left(10.29 \mathrm{t} \mathrm{ha}^{-1}\right)$ and harvest index (39.37\%). The lowest grain yield $\left(3.44 \mathrm{t} \mathrm{ha}^{-1}\right)$ and harvest index (36.54\%) were found in Basmati and the lowest straw yield (5.78 $\mathrm{t} \mathrm{ha}^{-1}$ ) was found in BRRI dhan50. Significant variation of grain and straw yields among the rice genotypes were reported elsewhere (Pal et al., 2016, Mittra, 2005, Muniruzzaman, 2004 and Hossain et al., 2003).

\section{Effect of nutrient management}

Nutrient management exerted significant influence on yield components and yield of fine rice varieties except panicle length and 1000-grain weight (Table 2). The highest plant height (69.00 $\mathrm{cm}$ ) was produced in $25 \%$ less than recommended dose of chemical fertilizer + poultry manure @ $2.5 \mathrm{t} \mathrm{ha}^{-1}$, which was statistically identical to $50 \%$ less than recommended dose of chemical fertilizer + vermicompost @ 10 t ha ${ }^{-1}$ and $25 \%$ less than recommended dose of chemical fertilizer + vermicompost @ $5 \mathrm{t} \mathrm{ha}^{-1}$. The highest number of total tillers hill $^{-1}$ (12.22) was produced in $25 \%$ less than recommended dose of chemical fertilizer + vermicompost @ $5 \mathrm{t} \mathrm{ha}^{-1}$ and the lowest one (9.55) was found in poultry manure $5 \mathrm{t} \mathrm{ha}^{-1}$. Similar results were reported by Shaha et al. (2014). The highest number of effective tillers hill ${ }^{-1}$ (10.56) was produced in $25 \%$ less than recommended dose of chemical fertilizer + vermicompost @ $5 \mathrm{t} \mathrm{ha}^{-1}$ while $50 \%$ less than recommended dose of chemical fertilizer + vermicompost @ $10 \mathrm{t} \mathrm{ha}^{-1}$ produced the highest non-effective tillers hill ${ }^{-1}$ (2.00). The highest number of grains panicle (95.11) was produced in $50 \%$ less than recommended dose of chemical fertilizer + poultry manure @ $5 \mathrm{t} \mathrm{ha}^{-1}$ and the lowest one (91.11) was found in vermicompost @ $10 \mathrm{t} \mathrm{ha}^{-1}$. Combined application of manures and fertilizers increased number of grains panicle ${ }^{-1}$ was reported elsewhere (Jahan et al., 2017; Sarkar et al., 2016; Parvez et al., 2008 and Rahman et al., 2007). The highest number of total spikelets panicle $^{-1}$ (107.7) was recorded in $50 \%$ less than recommended dose of chemical fertilizer + poultry manure at $5 \mathrm{t} \mathrm{ha}{ }^{-1}$ and the lowest one (99.78) was found in recommended dose of chemical fertilizers (i.e 250,126, 120, 100 and $10 \mathrm{~kg} \mathrm{N-P-K-S-}$ $\mathrm{Zn}$, respectively $\left.\mathrm{ha}^{-1}\right)$. The highest number of sterile spikelets panicle $^{-1}$ (14.33) was produced in poultry manure $5 \mathrm{t} \mathrm{ha}^{-1}$ while the lowest one was found in $50 \%$ less than recommended dose of chemical fertilizer + vermicompost @ $10 \mathrm{t} \mathrm{ha}^{-1}$. Recommended dose of chemical fertilizers (i.e. 250, 126, 120, 100 and $10 \mathrm{~kg}$ $\mathrm{N}-\mathrm{P}-\mathrm{K}-\mathrm{S}-\mathrm{Zn}$, respectively $\mathrm{ha}^{-1}$ ) produced the highest grain yield (4.31 $\mathrm{t} \mathrm{ha}^{-1}$ ). However, $25 \%$ less than recommended dose of chemical fertilizer + poultry manure $2.5 \mathrm{t} \mathrm{ha}^{-1}\left(4.15 \mathrm{t} \mathrm{ha}^{-1}\right)$ and $25 \%$ less than recommended dose of chemical fertilizer + vermicompost @ $5 \mathrm{t} \mathrm{ha}^{-1}$ (4.25 t ha $\left.{ }^{-1}\right)$ were as good as treatment of recommended dose of chemical fertilizers (i.e. 250, 126, 120, 100 and $10 \mathrm{~kg} \mathrm{N-P-K-S-Zn,} \mathrm{respectively} \mathrm{ha}{ }^{-1}$ in respect of grain yield. The lowest grain yield $\left(2.74 \mathrm{t} \mathrm{ha}^{-1}\right)$ was produced in poultry manure @ 5 t ha ${ }^{-1}\left(\mathrm{~N}_{1}\right)$ (2.87 t ha $\left.{ }^{-1}\right)$ and vermicompost @ $10 \mathrm{t}$ ha ${ }^{-1}$. Similar results were reported by Shaha et al. (2014) and Sarkar et al. (2014). The highest straw yield $\left(6.64 \mathrm{t} \mathrm{ha}^{-1}\right)$ was produced in $25 \%$ less than recommended dose of chemical fertilizer + poultry manure @ $2.5 \mathrm{t} \mathrm{ha}^{-1}$ and the lowest (5.04 t ha ${ }^{-1}$ ) was found in vermicompost @ $10 \mathrm{t} \mathrm{ha}^{-1}$ which was at par with poultry manure @ $5 \mathrm{t} \mathrm{ha}^{-1}\left(5.08 \mathrm{t} \mathrm{ha}^{-1}\right)$. Combined application of inorganic fertilizers with organic manures produced the highest straw yield (Jahan et al., 2017). The highest biological yield (10.80 $\left.\mathrm{t} \mathrm{ha}^{-1}\right)$ was found in $25 \%$ less than recommended dose of chemical fertilizer + poultry manure @ $2.5 \mathrm{t} \mathrm{ha}^{-1}$ which was at par with recommended dose of chemical fertilizers (i.e. 250, 126, 120, 100 and $10 \mathrm{~kg} \mathrm{N-P-K-S-Zn,} \mathrm{respectively} \mathrm{ha}{ }^{-1}$ ), and $25 \%$ less than recommended dose of chemical fertilizer + vermicompost @ $5 \mathrm{t} \mathrm{ha}^{-1}$ while the lowest one $\left(7.79 \mathrm{t} \mathrm{ha}^{-1}\right)$ was recorded in vermicompost @ $10 \mathrm{t} \mathrm{ha}^{-1}$. The highest harvest index was produced by recommended dose of chemical fertilizers (i.e. 250,126, 120, 100 and $10 \mathrm{~kg} \mathrm{N-P-K-S-Zn,} \mathrm{respectively} \mathrm{ha}{ }^{-1}$ ) (40.36\%) which was at par with $25 \%$ less than recommended dose of chemical fertilizer + vermicompost @ $5 \mathrm{t} \mathrm{ha}^{-1}$ (39.91\%) and $50 \%$ less than recommended dose of chemical fertilizer + vermicompost @ $10 \mathrm{t} \mathrm{ha}^{-1}$ (39.85\%) and the lowest one (35.24\%) was found in vermicompost @ 10 tha $^{-1}$.

Interaction effect of variety and nutrient management Crop characters, yield components and yield of aromatic fine rice were significantly influenced by the interaction between variety and nutrient management (Table 3 ). The tallest plant $(72.00 \mathrm{~cm})$ was recorded in Basmati fertilized with $25 \%$ less than recommended dose of chemical fertilizer + vermicompost @ $5 \mathrm{t}$ ha $^{-1}$ while BRRI dhan 63 fertilized with $50 \%$ less than recommended dose of chemical fertilizer + poultry manure @ $5 \mathrm{t} \mathrm{ha}^{-1}$ 


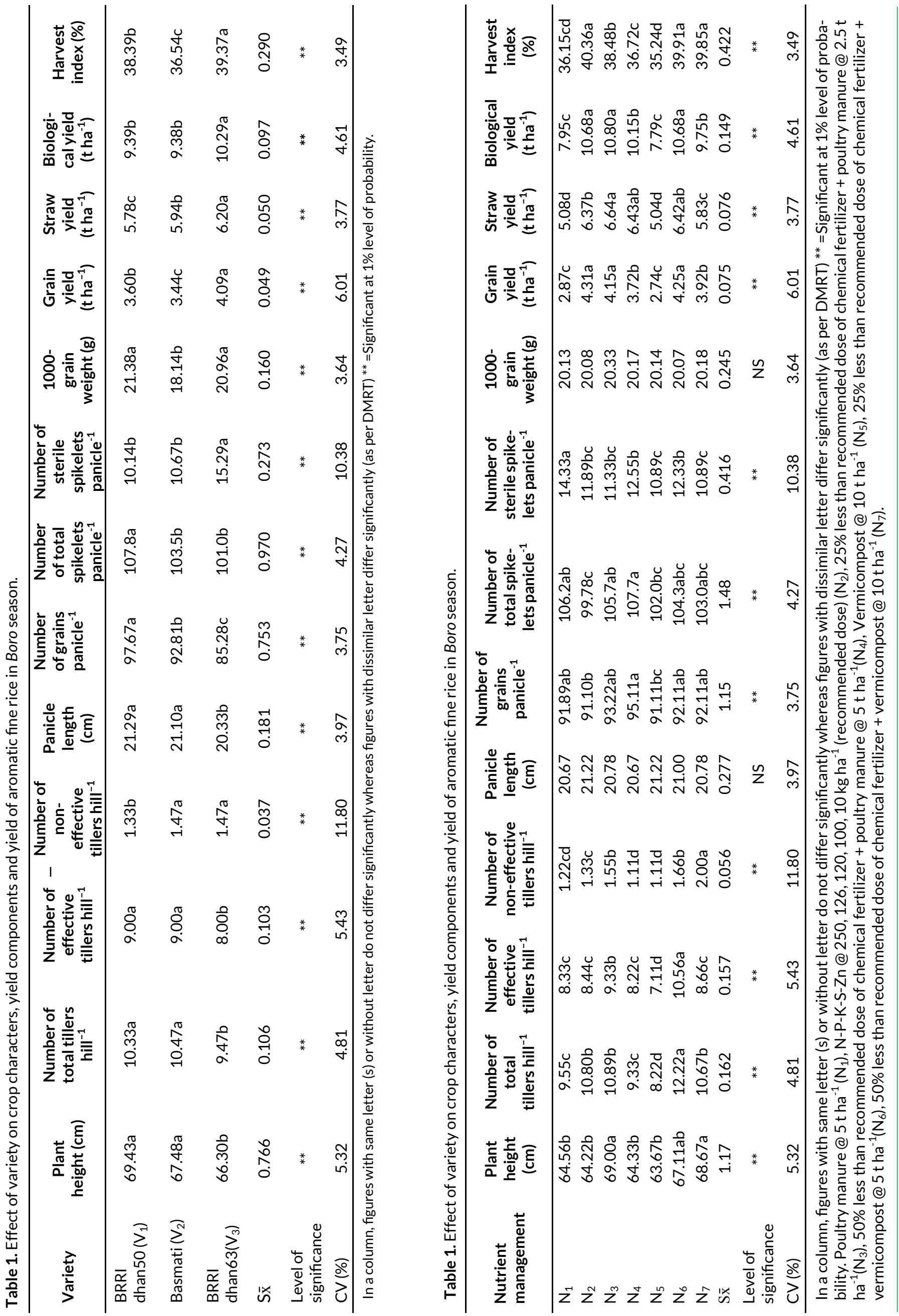




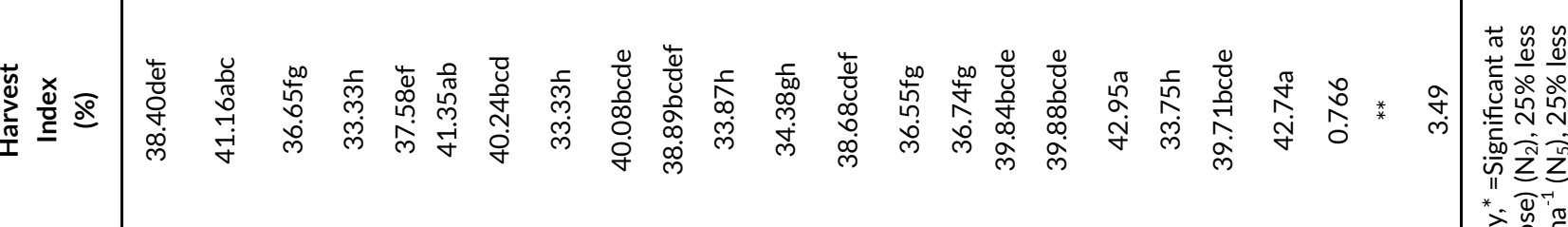

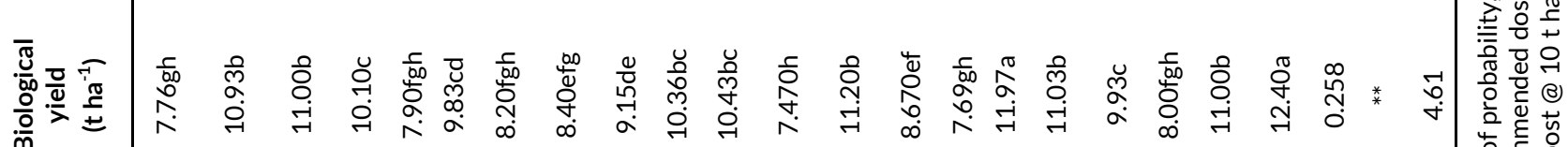

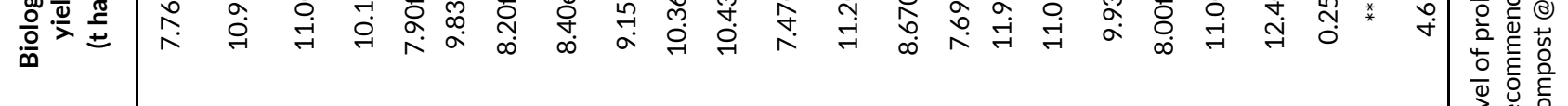

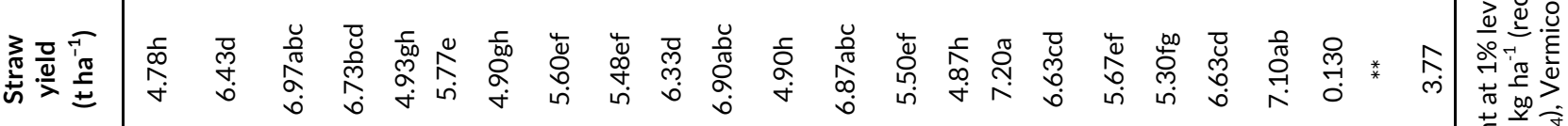

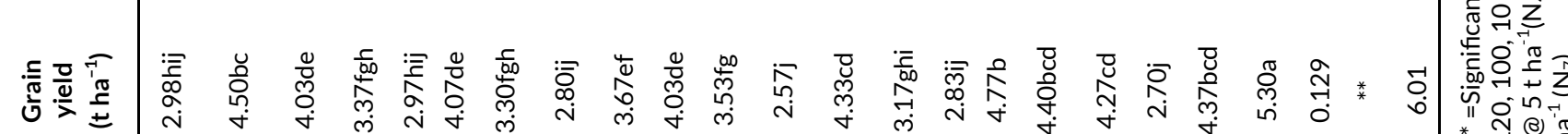

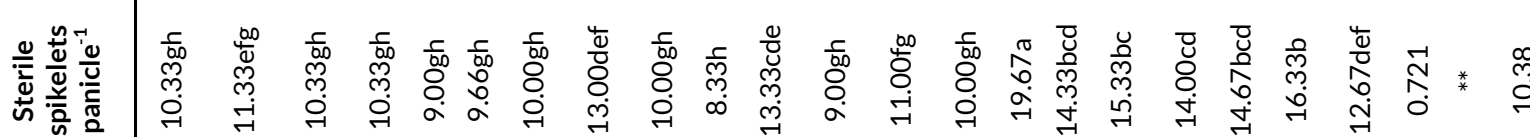

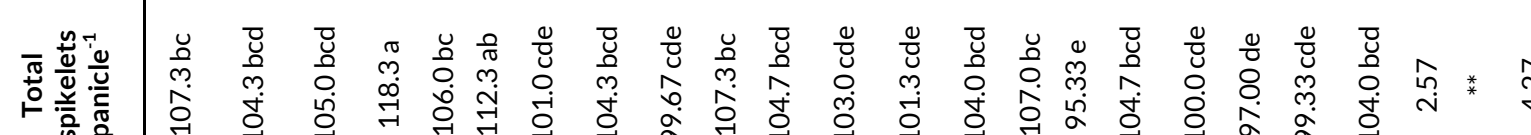

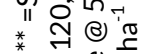

西

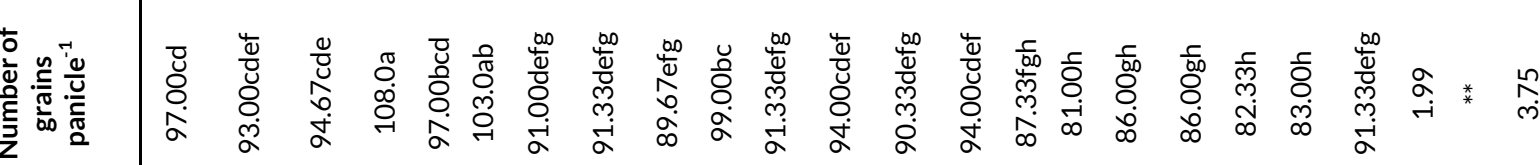

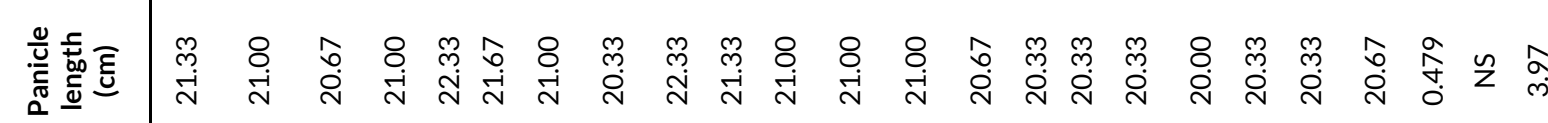

$\stackrel{2}{2}$

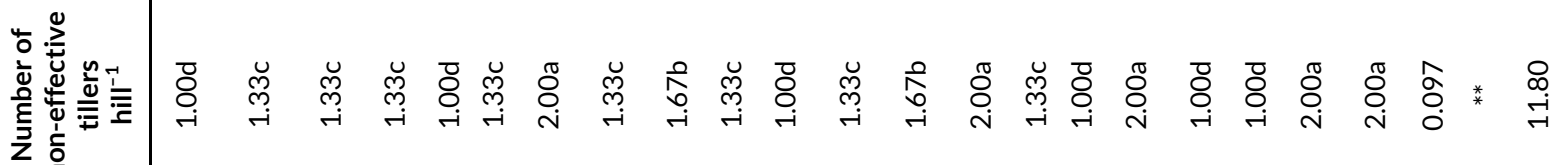

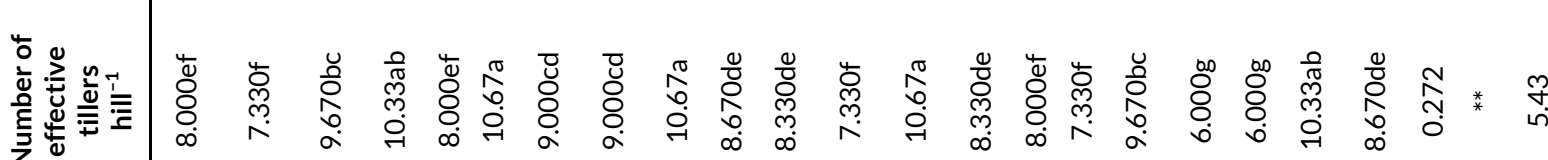

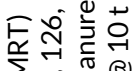

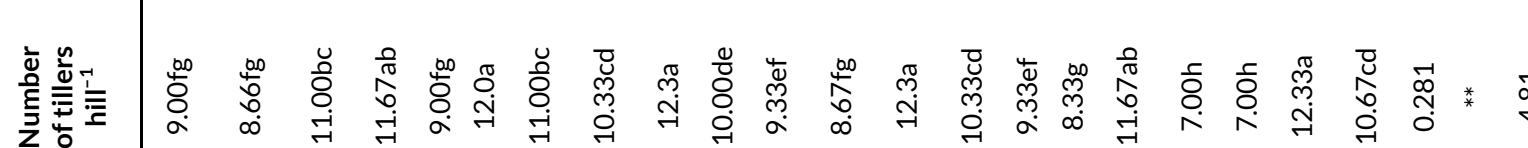


produced the shortest one $(57.00 \mathrm{~cm})$. The highest number of total tillers hill $^{-1}$ (12.33) was obtained in BRRI dhan63 fertilized with $25 \%$ less than recommended dose of chemical fertilizer + vermicompost @ $5 \mathrm{t} \mathrm{ha}^{-1}$ which was similar to BRRI dhan 50 fertilized with recommended dose of chemical fertilizers (i.e. 250, 126, 120, 100 and $10 \mathrm{~kg} \mathrm{N-P-K-S-Zn)} \mathrm{and} \mathrm{Basmati} \mathrm{along} \mathrm{with}$ $25 \%$ less than recommended dose of chemical fertilizer + vermicompost @ $5 \mathrm{t} \mathrm{ha}^{-1}$, BRRI dhan50 fertilized with $50 \%$ less than recommended dose of chemical fertilizer + vermicompost @ $10 \mathrm{t} \mathrm{ha}^{-1}$, Basmati fertilized with $50 \%$ less than recommended dose of chemical fertilizer + vermicompost $10 \mathrm{t} \mathrm{ha}^{-1}$, BRRI dhan63 fertilized with $25 \%$ less than recommended dose of chemical fertilizer + poultry manure $2.5 \mathrm{t} \mathrm{ha}^{-1}$, BRRI dhan63 fertilized with $25 \%$ less than recommended dose of chemical fertilizer + vermicompost @ $5 \mathrm{t} \mathrm{ha}^{-1}$ and BRRI dhan63 fertilized with $50 \%$ less than recommended dose of chemical fertilizer + vermicompost @ $10 \mathrm{t} \mathrm{ha}^{-1}$ produced the highest (2.00) number of non-effective tillers hill $\left.{ }^{-1}\right)$. The highest number of grains panicle $^{-1}(108.0)$ and number of total spikelets panicle ${ }^{-1}(118.3)$ were recorded in BRRI dhan50 fertilized with $50 \%$ less than recommended dose of chemical fertilizer + poultry manure @ $5 \mathrm{t}$ ha ${ }^{-1}$. BRRI dhan63 with poultry manure @ $5 \mathrm{t} \mathrm{ha}^{-1}$ produced the highest number of sterile spikelets panicle ${ }^{-1}$ (19.67) while Basmati along with $25 \%$ less than recommended dose of chemical fertilizer + poultry manure @ $2.5 \mathrm{t} \mathrm{ha}^{-1}$ produced the lowest one (8.33). The highest grain yield $\left(5.30 \mathrm{t} \mathrm{ha}^{-1}\right)$ was recorded in BRRI dhan63 fertilized with $50 \%$ less than recommended dose of chemical fertilizer + vermicompost @ $10 \mathrm{t} \mathrm{ha}^{-1}$ while the highest straw yield $\left(7.20 \mathrm{t} \mathrm{ha}^{-1}\right)$ was produced in BRRI dhan63 fertilized with recommended dose of chemical fertilizers (i.e. 250, 126, 120, 100 and $10 \mathrm{~kg}$ N-P-K-S-Zn, respectively ha ${ }^{-1}$ ). BRRI dhan63 fertilized with $50 \%$ less than recommended dose of chemical fertilizer + vermicompost @ $10 \mathrm{t} \mathrm{ha}^{-1}$ also produced the highest biological yield (12.40 $\mathrm{t} \mathrm{ha}^{-1}$ ) which was at par with BRRI dhan63 fertilized with recommended dose of chemical fertilizers (i.e. 250, 126, 120,

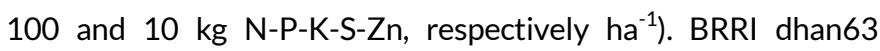
fertilized with $50 \%$ less than recommended dose of chemical fertilizer + poultry manure @ $5 \mathrm{t} \mathrm{ha}^{-1}$ produced the highest harvest index $(42.95 \%)$ which was statistically identical with BRRI dhan63 fertilized with $50 \%$ less than recommended dose of chemical fertilizer + vermicompost @ $10 \mathrm{t} \mathrm{ha}^{-1}$ and (42.74\%). Sarkar et al. (2014) reported similar trend in case of harvest index.

\section{Conclusion}

The results of this investigation revealed that the highest grain and straw yields were obtained in BRRI dhan63. Application of recommended dose of chemical fertilizers (i.e. 250, 126, 120, 100 and $10 \mathrm{~kg} \mathrm{~N}-\mathrm{P}-\mathrm{K}-\mathrm{S}-\mathrm{Zn}$, respectively $\mathrm{ha}^{-1}$ ) produced the highest grain yield $\left(4.31 \mathrm{t} \mathrm{ha}^{-1}\right)$ which was at par with $25 \%$ less than recommended dose of chemical fertilizer + vermicompost @ $5 \mathrm{t}$ $\mathrm{ha}^{-1}$ and $25 \%$ less than recommended dose of chemical fertilizer + poultry manure @ $2.5 \mathrm{t} \mathrm{ha}^{-1}$ while the lowest one $\left(2.74 \mathrm{t} \mathrm{ha}^{-1}\right)$ was found in vermicompost @ $10 \mathrm{t} \mathrm{ha}^{-1}$. BRRI dhan63 fertilized with $50 \%$ less than recommended dose of chemical fertilizer + vermicompost @ $10 \mathrm{t} \mathrm{ha}^{-1}$ produced the highest grain yield while the highest straw yield $\left(7.20 \mathrm{t} \mathrm{ha}^{-1}\right)$ was produced in BRRI dhan63 fertilized with recommended dose of chemical fertilizers (i.e. 250, 126, 120, 100 and 10 kg N-P-K-S-Zn, respectively $\left.\mathrm{ha}^{-1}\right)$. Therefore, it can be concluded that BRRI dhan63 can be grown with $50 \%$ less than recommended dose of chemical fertilizer + vermicompost @10 t ha ${ }^{-1}$ in Boro season to obtain the highest grain yield.

\section{ACKNOWLEDGEMENTS}

The financial assistance of the Ministry of Science and Technology, Govt. of the People's Republic of Bangladesh (39.00.0000.09.02.69.16-17/BS-49/63) to carry out the research work is thankfully acknowledged.

Open Access: This is open access article distributed under the terms of the Creative Commons Attribution License, which permits unrestricted use, distribution, and reproduction in any medium, provided the original author(s) and the source are credited.

\section{REFERENCES}

BBS, Bangladesh Bureau of Statistics (2016). The Yearbook of Agricultural Statistics of Bangladesh. Stat., Stat. Div., Minis. Plan., Govt. People's Repub., Bangladesh, Dhaka.pp.56-65.

FAO, Food and Agricultural Organization (2009). Production Year Book. Food and Agric. Organ. of the United Nations, Rome. 45: 72-73.

FAO, Food and Agriculture Organization (2004). FAO Indices of Food and Agricultural Production. Food Agric. Org., Italy. pp. 16-19.

Gomez, K.A. and Gomez, A.A. (1984). Statistical Procedures for Agricultural Research. Int. Rice Res. Inst., John Wiley and Sons. New York, Chichester, Brisbane, Toronto, Singapore. p. 680 .

Hossain, M.S., Mamun, A.A., Basak, R., Newaj, M.N. and Anam, M.K. (2003). Effect of cultivar and spacing on weed infestation and performance of transplant aman rice in Bangladesh. Pakistan Journal of Agronomy, 2(3): 169-178.

Jahan, S., Sarkar, M.A.R. and Paul, S.K. (2017). Effect of plant spacing and fertilizer management on the yield performance of BRRI dhan39 under Old Brahmaputra Floodplain Soil. Madras Agricultural Journal, 104 (1-3): 37-40.

Kirttania, B., Sarkar, M.A.R., Paul, S.K. and Islam, M.S. (2013). Morpho-physiological attributes of transplant Aman rice as influenced by variety, age of tiller seedlings and nitrogen management. Journal of Agroforestry and Environment, 7(2): 149-154.

Mittra, C.K. (2005). Effect of different levels of nitrogen on the yield performance and nitrogen use efficiency of five advance lines of rice in Boro season. MS Thesis, Dept. of Soil Science. Bangladesh Agril. Univ., Mymensingh. pp. 49.

Muniruzzaman, M. (2004). Screening and selection of advanced line of rice on the basis of nitrogen use efficiency. MS Thesis, Dept. of Soil Science. Bangladesh Agricultural 
University, Mymensingh.pp.51.

Pal, S., Paul, S.K., Sarkar, M.A.R. and Gupta, D.R. (2016). Response on yield and protein content of fine aromatic rice varieties to integrated use of cowdung and inorganic fertilizers. Journal of Crop and Weed, 12(1): 01-06.

Parvez, M.S., Islam, M.R., Begum, M.S., Rahman, M.S. and Abedin Miah, M.J. (2008). Integrated use of manure and fertilizers for maximizing the yield of BRRI dhan30. Journal of Bangladesh Society of Agricultural Science and Technology, 5 (1\&2): 257-260.

Paul, S.K., Islam, M.S., Sarkar, M.A.R., Das, K.R. and Islam, S.M.M. (2016). Impact of variety and level of nitrogen on the growth performance of HYV transplant Aman rice. Progressive Agriculture, 27: 32-38.

Rahman, M.H., Khatun, M.M., Mamun, M.A.A., Islam, M.Z. and Islam, M.R. (2007). Effect of number of seedling hill ${ }^{-1}$ and nitrogen level on growth and yield of BRRI dhan32. Journal of Soil and Nutrition, 1(2): 01-07.

Ray, S., Sarkar, M.A.R., Paul, S.K., Islam, A.K.M.M. and Yeasmin, S.
(2015). Variation of Growth, Yield and Protein Content of Transplant Aman Rice by Three Agronomic Practices. Agricultural and Biological Sciences Journal, 1(4) 167-176.

Sarkar, S.K., Sarkar, M.A.R., Islam, N. and Paul, S.K. (2014). Yield and quality of aromatic fine rice as affected by variety and nutrient management. Journal of the Bangladesh Agricultural University, 12(2): 279-284.

Sarkar, S.K., Sarkar, M.A.R., Islam, N. and Paul, S.K. (2016). Morpho-physiological attributes of three HYV aromatic fine rice varieties as affected by integrated nutrient management. Journal of Agroforestry and Environment, 10 (1): 57-61.

Shaha, U., Bhuiya, M.S.U. and Paul, S.K. (2014). Integrated use of cowdung and inorganic fertilizer on the performance of modern varieties of transplant Aman rice. Journal of Agroforestry and Environment, 8(2): 81-84.

UNDP and FAO (1988). Land Resources Appraisal of Bangladesh for Agricultural Development, Report No. 2. Agro-ecological Regions of Bangladesh. United Nations Dev. Prog. And Food and Agric. Organ. pp. 212-221. 